Код ББК: 67.402

\title{
ПРОБЛЕМЫ ПРОВЕДЕНИЯ КАМЕРАЛЬНЫХ НАЛОГОВЫХ ПРОВЕРОК
}

\author{
(c) 2020 Захаров Алексей Леонидович \\ кандидат юридических наук \\ Самарский государственный экономический университет, Россия, Самара
}

(c) 2020 Радица Марина Дмитриевна

магистрант по направлению подготовки правовое обеспечение

бюджетно-финансовой деятельности и налогообложения

(c) 2020 Изосимова Алина Сергеевна

магистрант по направлению подготовки правовое обеспечение

бюджетно-финансовой деятельности и налогообложения

В рамках данной статьи анализируются важнейшие проблемы, возникающие в процессе и негативно влияющие на качество проведения камеральных налоговых проверок в Российской Федерации. Рассмотрены факты, предопределившие возникновение таких проблем и предложены пути их решения. Предоставлены некоторые способы, которыми следовало бы руководствоваться для выхода из затруднительных ситуаций при проведении камеральных налоговых проверок.

Ключевые слова: налоговый контроль, камеральная налоговая проверка, налоговое законодательство, налоговое право.

В механизме налогового контроля камеральная налоговая проверка занимает одно из основных мест, так как именно она является наиболее эффективным методом, позволяющим предупредить и пресечь правонарушения и преступления в налоговой сфере на их начальной стадии. Согласно ст. 88 Налогового кодекса Российской Федерации (принятым Государственной Думой 16 июля 1998 года) (далее - НК РФ) камеральная налоговая проверка проводится по месту нахождения налогового органа на основе налоговых деклараций и документов, представленных налогоплательщиком, служащих основанием для исчисления и уплаты налога, а также других документов о деятельности налогоплательщика, имеющихся у налогового органа. Предусмотренные в ст. 88 НК РФ правомочия, осуществляемые налоговыми органами в процессе камеральных проверок (возможность затребовать у налогоплательщика дополнительные сведения, получать объяснения и дополнительные документы и т.д.), позволяют им в рамках данной формы налогового контроля выявить те проблемные моменты в деятельности налогоплательщика, более глубокий анализ которых может привести к столь желаемому для любого налогового инспектора результату, а именно доначислению в бюджет налогов и взысканию штрафных санкций.
В связи с вышесказанным становится очевидным, что именно камеральные налоговые проверки становятся тем звеном, усилив которое налоговые органы смогут резко поднять эффективность своей работы.

Большинство налогоплательщиков сдают декларации по НДС за I квартал успешно с первого раза. Это, однако, не значит, что у ФНС не возникнет вопросов к данным: после приема отчетности начинается камеральная проверка.

Сначала проверяется выполнение контрольных соотношений. Обнаружив ошибку, ФНС высылает компании требование о представлении пояснений по контрольным соотношениям. Поскольку это требование о пояснениях, на него распространяются нормы п. 5.1 ст. 23 и ст. 88 HK РФ: отправить квитанцию нужно в течение 6 рабочих дней, на ответ отводится 5 рабочих дней.

Если компания признает указанные ошибки, она направляет уточненную декларацию. Если организация настаивает, что приведенные в декларации данные верны, она отправляет пояснения.

Следующий этап - сопоставление информации о поставщике и о покупателе. Если ФНС выявит разногласия, компания получит требование о представлении пояснений по расхождениям. По итогам отчетности за I квар- 
тал такие требования рассылаются в пилотном режиме и только по части расхождений. Во II квартале их число увеличивается. В ответе налогоплательщика должно быть две таблицы. В первой приводятся сведения, которые он подтверждает. Во вторую идут данные, которые он исправляет. Правки даются в две строки: первая копируется из требования, а во второй заполняются те ячейки, в которых данные меняются. Корректировать можно только те данные, которые не влияют на сумму НДС. По остальным составляется уточненная декларация.

Ответ на требование по расхождениям можно направить как на бумажном носителе, так и в электронном виде - через систему электронной отчетности. Ответ на требование - процедура непростая, тем более что на нее отводится законодателем всего 5 дней. До тех пор, пока компании не перешли на ЭДО с контрагентами, самый надежный способ исключить разногласия - сверяться с контрагентами до подачи декларации.

Конечно же, налоговые органы вправе потребовать от налогоплательщиков представления первичных документов и надо сказать, что в истребовании таких документов ничего предосудительного нет. Но на практике, как правило, запрашивается множество первичных документов, а анализируется только часть из них. Подобное положение дел, конечно же, требует определенной корректировки с точки зрения методологии проведения таких проверок. Поэтому, прежде чем запрашивать у налогоплательщика именно первичные документы, следует убедиться в их необходимости.

Статьи 82,87 НК РФ определяют основные формы налоговых проверок: это камеральная налоговая проверка (ст.88 НК РФ). В п.3 ст.7 Закона РФ «О налоговых органах Российской Федерации сказано, что «налоговым органам предоставляется право осуществлять налоговый контроль путем проведения налоговых проверок, а так же в других формах, определенных НК РФ».

Камеральная налоговая проверка - один из основных видов налогового контроля. Вопрос проведения камеральных налоговых проверок имеет в себе как практическую, так и теоретическую актуальность. На сегодняшний день существует большое количество исследований по данному вопросу, однако, эта тема не теряет своей актуальности. Хотелось бы обозначить некоторые аспекты по проблематике проведения камеральных налоговых проверок.

Во-первых, существует некоторое непонимание в разделении камеральной и выездной проверок.

Камеральная проверка в отличие от выездной нацелена на своевременное выявление ошибок в налоговой отчётности и оперативное реагирование налоговиков на обнаруженные нарушения, что позволяет смягчить для налогоплательщиков последствия от неправильного применения ими норм налогового законодательства.

Так что камеральная и выездная налоговая проверка являются самостоятельными и отдельными формами налогового контроля. Кроме того, так как выездная проверка и камеральная проверка представляют собой самостоятельные и независимые формы налогового контроля, то не выявление инспекцией в рамках проведения выездной проверки неправомерных действий налогоплательщика не исключает возможности установления и доказывания данных фактов в рамках проведения камеральной налоговой проверки.

Нарушения законодательства РФ о налогах и сборах, выявленные в ходе налоговых проверок, налоговые органы вносят в акт проверки сроки составления которого установлены Налоговым кодексом. Поскольку в России налоговые органы проводят два вида налоговых проверок - выездные и камеральные (статьи 82 и 87 Налогового кодекса РФ), значительно отличаются порядок и сроки акта проверки в зависимости от вида налоговой проверки. Акт камеральной налоговой проверки составляется в срок 10 дней по окончании камеральной налоговой проверки (ч.1 ст.100 НК РФ). Кажется, все просто и однозначно, тем более, что акт камеральной налоговой проверки составляется по правилам статьи $100 \mathrm{HK}$ РФ. На практике основная проблема и риски налогоплательщиков заключены в отсутствии информирования о начале камеральной налоговой проверки, завершении проверки, и исчислении срока окончания камеральной налоговой проверки.

Что касается исчисления срока камеральной налоговой проверки, то, на первый взгляд все просто - правила проведения камеральных налоговых проверок изложены в ст. 88 Налогового кодекса РФ. Камеральная налоговая проверка проводится налоговым органом после получения от налогоплательщика налого- 
вой декларации по налогу любого вида. Срок проведения камеральной проверки зависит от вида налога, по которому представлена декларация. За исключением налоговых деклараций по НДС срок камеральной налоговой проверки составляет три месяца, для налоговых деклараций по НДС - два месяца (ч.2 ст. 88 НК РФ). Срок камеральной налоговой проверки начинает течь с даты получения налоговой декларации налоговым органом. Много лет, регулярно приходится сталкиваться с ситуациями, когда налоговый инспектор не успевает провести камеральную проверку декларации в установленный срок. Риск налогоплательщиков в том, что это не является препятствием для составления акта «за сроком» проверки, рассмотрения акта, и вынесения соответствующего решения, например, о снятии вычетов.

Типичное нарушение при оформлении акта проверки: налоговики регулярно «забывают» приложить к акту налоговой проверки документы, подтверждающие совершение налогового правонарушения. Даже по требованию налогоплательщика уклоняются приложить документы контрагентов и иных лиц, ссылаясь на банковскую тайну, на налоговую тайну, на тайну персональных данных и т.п.

Общеизвестно, налоговики регулярно не соблюдают установленный срок оформления акта камеральной налоговой проверки, и акта выездной налоговой проверки. Допускают превышение срока составления акта налоговой проверки (и камеральных и выездных налоговых проверок).

Допущенное превышение срока составления акта - является процессуальным нарушением, и не поименовано Налоговым кодексом существенным нарушением, делающим безусловно недействительным акт налоговой проверки, или вызывающим безусловную отмену решения по налоговой проверке (ч.14 ст.101 НК РФ). Мотивируя такой правовой позицией, суды отказываются защищать налогоплательщиков исключительно на фактах пропуска налоговиками срока составления акта налоговой проверки. Такая правовая позиция сохраняется много лет, и подтверждена многочисленной судебной практикой, в том числе практикой Верховного Суда РФ в 2019 году.

Как правило, одновременно с пропуском срока изготовления акта налоговой проверки налоговики совершают пропуск срока вручения акта. Наиболее «плачевны» для налогоплательщиков такие нарушения во время камеральных налоговых проверок, когда о проверке налогоплательщик не информирован.

Такое очевидное нарушение положений Налогового кодекса РФ суды так же не рассматривают в качестве достаточного основания для отмены акта налоговой проверки и соответствующего решения налогового органа.

В октябре 2019 г. Верховный Суд РФ отказался поддержать налогоплательщика в налоговом споре по решению налоговой инспекции, вынесенному по акту камеральной налоговой проверки, составленному через 2,5 года после сдачи налоговой декларации (Определение ВС РФ № 308-ЭС19-13627 от 01.10.2019). Верховный Суд поддержал правовые позиции нижестоящих судов.

Финансовая безграмотность налогоплательщиков в момент, когда происходит попытка уклонения от ответственности, порождает новые сложности в работе налоговых органов.

Ниже перечислен ряд нарушений, который чаще всего выявляют налоговые органы при камеральной проверке.

1. Использование сомнительных контрагентов. На практике существует ряд случаев, когда используется деятельность фирм-однодневок.

2. Нарушения по списанию расходов в холдингах или группах компаний. Для собственника группа компаний - единый бизнес. Некоторые расходы сложно разделить по разным компаниям. Например, рекламу, аренду и пр. Такие расходы ошибочно списывают на одну компанию. А следует распределять пропорционально полученной выручке.

3. Нарушения при отсутствии у проверяемого документов. Кажется, если нет документов, значит нет объекта для проверок налоговыми органами. Это мнение является ошибочным.

4. Налоговые схемы. Они выявляются как при выездных, так и при камеральных проверках. Схем много, и с каждым годом становится больше. Пожалуй, выделим самые распространенные ситуации уклонения от ответственности:

- дробление бизнеса, не обусловленное объективными факторами, а преследующее только экономию на налогах. Например, несколько компаний с одинаковыми функциями, но разными налоговыми режимами. Обычно, эти компании работают на грани лимитов по спецрежимам.

- регистрация работников в качестве ИП 
или самозанятых. Такой тип уклонения уже давно стал известен налоговым органам.

- руководитель компании - управляющий ИП. Почти все бизнесмены слышали про эту схему, но не знают, как безопасно ее воплотить в жизнь. Результатом становится налоговая ответственность.

- проблемы с трансфертным ценообразованием. Обычно попадаются те, кто накапливает НДС на однодневки (а затем и не платит его), которые обнаруживают признаки взаимозависимости с основной компанией. Это происходит с помощью завышения наценки на товары/услуги.

Следующая проблема напрямую связана с истребованием документов при проведении камеральной проверки. На практике часто возникает вопрос о возможности истребования дополнительного пакета документов сотрудниками налогового органа. Существенно расширился перечень случаев, когда налоговики могут истребовать у налогоплательщика документы дополнительно к представленной декларации по НДС. Конечно, в первую очередь это связано с тем, что с 2015 года налоговая служба ввела механизм, позволяющий отслеживать всю «цепочку» прохождения НДС от производителя до конечного покупателя.

Очевидно, что цель истребования документов в этом случае - выяснить, кто же представил в налоговые органы неверные сведения. При этом право потребовать дополнительные документы появляется у инспектора только при выявлении расхождений, которые свидетельствуют о занижении суммы НДС к уплате или о завышении суммы налога к возмещению.

Попросить такие документы инспектор вправе не только если выявлены противоречия в сведениях об операциях, которые содержатся в декларации по НДС, но и если сведения, указанные в вашей декларации, не соответствуют данным, которые указали в своих декларациях или журналах учета счетов-фактур ваши контрагенты.

Еще одно новшество,- предоставление налоговым органам права в рамках камеральной проверки проводить осмотр территорий, помещений, документов и предметов налогоплательщика (п. 1 ст. 92 НК РФ в новой редакции). Раньше такая возможность у инспекторов была только в рамках выездной проверки. Теперь же законодатель вслед за руководством ФНС Рос- сии явно намерен снизить количество выездных проверок, предоставив налоговикам возможность одновременно проверять расхождения в налоговой отчетности не только по документам, но и в реальности.

Стоит отметить, что основной задачей Федеральной налоговой службы остается улучшение качества взаимодействия с налогоплательщиками, информационная открытость, четкость, формирование налоговой культуры и налогового подсознания граждан. Иными словами, налоговые органы делают все возможное для того, чтобы даже не очень осведомленному налогоплательщику было комфортно и просто исполнять свои налоговые обязательства. Однако, анализ судебной практики (в рамках арбитражного процесса) часто свидетельствует о противоречивых заключениях принимаемых судами различных инстанций, что подтверждает сложность принятия решений по различным ситуациям.

Таким образом, авторы данной статьи осветили основные проблемы проведения камеральных налоговых проверок. Приведенные выше выводы ставят целью вынести на обсуждение научного сообщества названные проблемы, для дальнейших изменений в нормативные правовые акты и правоприменительную практику. Необходимо усовершенствовать различные сферы налогообложения для того, чтобы решить некоторые проблемы проведения камеральных налоговых проверок. Итак,

- требуется доработка норм налогового законодательства, в том числе относительно сроков составления актов налоговой проверки и сроков проведения налоговых проверок;

- необходимо создание единой базы налоговых органов, которая содержала бы подробную информацию о налогоплательщиках, включающая в себя сведения о деятельности хозяйствующих субъектов;

- требуется создание единой базы для регулирования и отслеживания действий налоговых органов при работе с организациями, которые осуществляют деятельность в сфере экспорта, целесообразно заключение международных договоров;

- необходимо на законодательном уровне закрепить требования к собранным доказательствам, чтобы исключить дезориентацию сотрудников налогового органа в данном вопросе. 


\section{Библиографический список}

1. Налоговый кодекс Российской Федерации (часть первая) от 31.07.1998 № 146-ФЗ[Электронный ресурс]: Доступ из справочно-правовой системы «Консультант плюс» (дата обращения 15.02.2020).

2. Лобанов А.В.Пути повышения эффективности налогового контроля на современном этапе налоговой реформы: автореферат диссертации к.э.н.- Москва, 2010.-214 с.

3. Шемякина М. С. Налогооблагаемые ресурсы как элемент архитектоники налогового потенциала // Новый университет. Серия: Экономика и право. 2015. № 2 (48). С. 27-30

4. Чистова М.В., Галаев А.М. Пути повышения эффективности контрольной работы налоговых органов // Научно-методический электронный журнал «Концепт». 2017. Т. 2. С. 588. 